\title{
Perilaku Pedagang Pasar Bandar Kecamatan Mojoroto Kota Kediri Dalam Prespektif Prinsip Dasar Pasar Islami
}

\author{
Dennis Ulfan Nanda ${ }^{1)}$, Khusnul Fikriyah ${ }^{2)}$ \\ ${ }^{1,2}$ Fakultas Ekonomi, Universitas Negeri Surabaya \\ *Email korespondensi: dennisnanda16081194052@ mhs.unesa.ac.id
}

\begin{abstract}
Buying and selling activities are one of the community's needs as facilities and infrastructure of daily needs. Here, the market as one of the tools where there is buying and selling interaction. The marketing environment can change and be uncertain and provide not only opportunities but also threats. The Bandar market is a traditional market that sells the needs for essential materials at an affordable price for the community. The purpose of this research is to determine the behaviour of traders and compliance with the basic principles of Islamic markets. This type of research uses descriptive qualitative research. Data collection techniques using observation, interview, and documentation. The conclusion of this research is the traders' behaviour in the Bandar market which already tolerable and precise even though the city market is essentially a conventional market, and traders in the Bandar market already apply the principle of Ar-Ridhla, healthy competition, honesty, openness, and justice properly.
\end{abstract}

Keywords : Traditional market, behavior of traders, basic principles of islamic market

Saran sitasi: Nanda, D. U., \& Fikriyah, K. (2020). Perilaku Pedagang Pasar Bandar Kecamatan Mojoroto Kota Kediri Dalam Prespektif Prinsip Dasar Pasar Islami. Jurnal Ilmiah Ekonomi Islam, 6(03), 588-597. doi:http://dx.doi.org/10.29040/jiei.v6i3.1364

\section{DOI: http://dx.doi.org/10.29040/jiei.v6i3.1364}

\section{PENDAHULUAN}

Indonesia merupakan salah satu negara yang jumlah penduduk muslimnya terbanyak di dunia, berdasarkan statistik data dari Badan Pusat Statistik (BPS) pada sesnsus penduduk ditahun 2010, tercatat $87,2 \%$ atau (207,2 jiwa) dari 236,4 juta jiwa seluruh masyarakat yang beragama Islam. Dan diperkirakan pada tahun 2020, penduduk muslim Indonesia akan mencapai 229,62 juta jiwa. Maka dari itu, penduduk muslim tentunya memiliki pengaruh yang sangat besar khususnya dalam perkembangan perekonomian negara (Puspitasari, 2019). Islam merupakan tatanan kehidupan yang sangat lengkap (a complete way of life) karena didalamnya terdapat prinsip-prinsip yang terkonsep dengan sangat baik dalam mengatur segala aspek kehidupan manusia (Ramadhan, 2015). Selain itu ada ibadah yang merupakan bentuk penghambaan diri seorang muslim kepada Allah SWT, dimana ada ibadah khashah seperti solat, zakat, puasa, haji, dan lain-lain dan juga ada ibadah 'ammah atau segala amal yang telah diizinkan Allah SWT misalnya dalam hal muamalah yang mana mengatur hubungan manusia dalam interaksi sosial sesuai syariat, salah satunya yaitu muamalah dalam hal transaksi jual beli atau berbisnis (Rohmansyah, 2017). Berbisnis merupakan aktivitas yang sangat disarankan dalam ajaran islam. Bahkan, Rasulullah SAW sendiri pun telah bersabda dalam sebuah hadist "Hendaklah engkau berdagang sebab didalamnya terdapat $90 \%$ pintu-pintu rizki." (HR Ahmad). melalui jalan perniagaan inilah pintupintu rizki akan dapat terbuka sehingga nikmat Allah SWT terpancar daripadanya (Rivai, 2010).

Dalam ruang lingkup jual beli, seorang pedagang mengejar profit merupakan suatu hal yang bisa dibilang sangat wajar, akan tetapi mencapai keuntungan tersebut tidak sembarangan perlu memperhatikan pihak lain. Salah satu bentuk perhatian tersebut yaitu dengan berperilaku etis dalam berdagang dengan mengimplementasikan nilai-nilai moril dalam kegiatan berdagang telah ditetapkan dalam ajaran Islam dimana Islam sudah memberikan batasan yang jelas atau suatu batasan antara hal-hal 
yang boleh dikerjakan dan juga hal-hal yang tidak boleh dikerjakan, seperti menghalalkan segala cara berupa kecurangan, penipuan, menyuap, sumpah palsu, riba, dan perbuatan-perbuatan yang tidak boleh lainnya. Suatu batasan itulah yang biasa dikenal dengan istilah etika (Amalia, 2014). Selain menerapkan etika berbisnis, dalam berniaga sebagai umat muslim juga harus menerapkan etika sesuai syariah. Karena bisnis bukan sekedar mencari profit saja, akan tetapi juga berkaitan dengan aspek sosial dan psikologi individu, oleh sebab itu sangat diperlukan etika bisnis yang kokoh supaya perilaku pegiat bisnis (pedagang, produsen, sales, distributor, advertising, dan sebagainya) tidak sampai membuat rugi secara sosial ekonomi, dan tidak membuat rugi pemanfaatan konsumen (Fauzia, 2017).

Aktivitas berdagang adalah salah satu kebutuhan pokok masyarakat sebagai sarana dan prasarana dalam menunjang kebutuhan hidup sehari-hari. Salah satu sarana tempat berdagang atau berniaga itu adalah pasar, dalam lingkungan pemasaran serba tidak pasti dan dapat berubah serta memberikan peluang dan ancaman. Di banyak pasar tradisional sudah banyak dilakukan tera ulang timbangan dari pihak pengelola pasar unuk meminimalisir tindakan curang pedagang. Namun hal itu tidak membuat para pedagang memperbaiki perilakunya. Seperti yang terjadi di Pasar Pharaan Sentani, Papua yang pedagangnya tidak jujur terkait timbangan. Modusnya, saat petugas pasar melakukan (sweeping), para pedagang nakal mengganti timbangan dengan ukuran valid. Bila petugas sudah pergi, mereka ganti dengan timbangan yang sudah dimodifikasi sehingga ukuran bisa berkurang beberapa ons dari ukuran yang seharusnya. Kecurangan ini banyak dilakukan oleh pedagang beras, gula, kacang, dan barang dagangan lainnya yang memerlukan timbangan (tabloidjubi.com, 2019).

Kejujuran pedagang merupakan modal awal untuk tetap menjaga kelancaran usahanya. Kejujuran dalam menyalurkan informasi sangat dibutuhkan oleh pembeli atau konsumen. Nilai dari kejujuran telah dipraktikkan oleh Rasulullah SAW. Nabi pernah bersabda dalam sebuah hadist "Sesungguhnya para pedagang (pengusaha) akan dibangkitkan pada hari kiamat sebagai para penjahat, kecuali pedagang yang bertakwa kepada Allah SWT, berbuat baik, dan jujur" (HR Tirmidzi). Dan juga hadist nabi lainnya yang berbunyi "Seorang muslim adalah saudara bagi muslim yang lainnya, maka tidak halal bagi seorang muslim yang menjual barang cacat kepada saudaranya, kecuali jika dia menjelaskan" (HR Ibnu Majah). Serta sebagaimana firman Allah SWT dalam Al-Qur'an surat Asy-Syu'ara ayat 181-183:

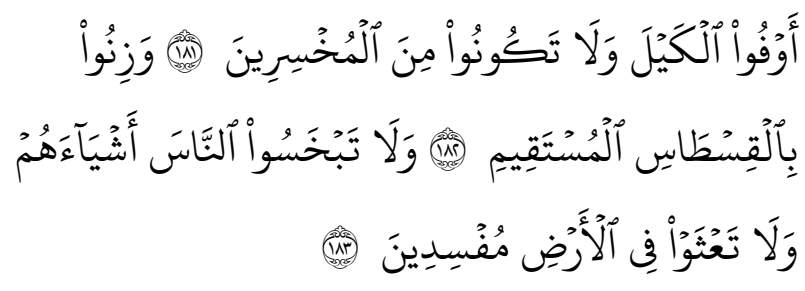

Artinya: "Sempurnakanlah takaran dan janganlah kalian Termasuk orang-orang yang merugikan;181. Dan timbanglah dengan timbangan yang lurus ;182. Dan janganlah kalian merugikan manusia pada hakhaknya dan juga janganlah kalian merajalela di muka bumi dengan membuat kerusakan;183."

Maksud dari ayat diatas adalah Allah SWT telah memberi kabar kepada seluruh umat manusia pada umumnya, dan khusunya kepada para pelaku bisnis atau pengusaha untuk berperilaku jujur dalam menjalankan segala bisnisnya dalam bentuk apapun, adanya sebuah penyimpangan dalam menakar, menimbang, dan mengukur barang merupakan salah satu contoh suatu kecurangan dalam berdagang (Arifin, 2013).

Kelebihan dari pasar tradisional adalah harga dari produk-produk yang dijual sangat bersahabat dengan masyarakat, sehingga bagi masyarakat harganya terbilang murah, sebagaimana fungsi pasar pada umumnya. Menjaga relasi antara pedagang dan pembeli, stok dagangan yang lengkap juga menjadi alasan masih banyak masyarakat yang memilih pasar tradisional (Faidah, 2020). Dengan mayoritas pedagangnya beragama muslim, menjadi fokus dalam penelitian ini tentunya melaksanakan kegiatan berdagang sesuai prinsip dasar pasar islami. Namun juga tidak bisa dipungkiri dengan berbagai perilaku dari penjual dan pembeli yang dapat mengakibatkan adanya ketersinggungan dan ketidak sesuaian dalam berakad mengenai kesepakatan harga, dan sebagainya. Dan juga ada sedikit perselisihan akibat penjual atau pembeli mempertahankan pendapat yang sudah jelas bertolak belakang dengan etika bisnis Islam. Maka penelitian ini bertujuan untuk mengetahui perilaku pedagang pasar Bandar di Kecamatan Mojoroto Kota Kediri. Dan juga untuk mengetahui perilaku pedagang pasar Bandar di Kecamatan Mojoroto Kota Kediri dalam prespektif prinsip dasar pasar islami.

Dalam (KBBI) Kamus Besar Bahasa Indonesia, perilaku merupakan reaksi atau tanggapan individu 


\section{Jurnal Ilmiah Ekonomi Islam, 6(03), 2020, 590}

yang diwujudkan dalam gerakan (sikap), tidak saja gerak-gerik badan atau ucapan. Dalam kehidupan sehari-hari istilah perilaku disamakan dengan tingkah laku. Menurut (Notoatmodjo, 2010) perilaku adalah suatu perbuatan atau tindakan organisme atau makhluk hidup. Perilaku manusia pada dasarnya merupakan suatu kegiatan dari manusia itu sendiri yang mempunyai lingkup yang luas diantaranya berkomunikasi, peka terhadap lingkungan sekitar, tertawa, membaca, dan sebagainya. Sedangkan menurut (Dewi, 2011) tingkah laku manusia adalah suatu perilaku yang dimiliki oleh manusia dan dipengaruhi oleh adat, nilai, etika, sikap, emosi, kekuasaan, dan sebagainya. Perilaku seseorang dapat dibedakan ke dalam perilaku wajar, perilaku aneh, dan perilaku menyimpang.

menurut (Christine, 2008) Pedagang adalah seorang atau badan yang melakukan transaksi jual beli barang atau jasa disuatu pasar. Aktivitas berdagang pada umumnya adalah aktivitas pembelian barang untuk dijual lagi. Adapun pedagang dikelompokkan jadi tiga, yaitu : pedagang besar/distributor/agen tunggal, pedegang menengah, pedagang eceran. Dapat disimpulkan bahwa yang dimaksud perilaku pedagang adalah suatu reaksi atau tanggapan dari seorang pedagang terhadap rangsangan atau lingkungan yang ada disekitar. Perilaku pedagang juga merupakan sebuah sifat yang dimiliki oleh setiap pelaku bisnis, untuk menerapkan reaksi dari keadaan yang terjadi sekarang.

Menurut (Karim, 2010) pasar yaitu keadaan atau lokasi yang mempertemukan antara permintaan (penjual) atau penawaran (pembeli) untuk setiap jenis barang, jasa atau sumber daya. Sedangkan menurut (Malano, 2011) pasar tradisional merupakan tempat dimana ada pedagang dan pelanggan saling bertemu secara langsung untuk bertransaksi, tawar menawar, menimbang dan menakar suatu barang dagangan, serta adanya bangunan berupa gerai, kios, los ataupun dasaran terbuka. Dan sebagian besar menjual kebutuhan pokok sehari-hari seperti bahan-bahan makanan yang berupa buah, sayur mayur, ikan, daging telur, pakaian, barang elektronik, dan lain-lain. Selain itu, ada juga yang berjualan jajanan tradisional seperti klepon, onde-onde, cenil, lemper dan aneka barangbarang lainnya. Pasar seperti ini masih banyak dijumpai di wilayah Indonesia, dan umumnya berada dekat degan lokasi pemukiman agar memudahkan masyarakat untuk pergi ke pasar. Keberadaan pasar tradisional telah membaur menjadi satu dalam perkembangan ekonomi dan masyarakat di sebuah daerah. Pasar tradisional banyak menyediakan tempat untuk berinteraksi langsung antar masyarakat untuk melakukan aktivitas perdagangan. Adanya pasar tradisional menjadi bukti nyata bagi kualitas hubungan antara pemerintah bagi masyarakat (Lukito, 2018).

Menurut (Aziz, 2013), pentingnya pasar sebagai faasiltas bagi para penjual dan pembeli untuk bertransaksi, bukan hanya dipandang dari fungsi secara fisikmya, namun perilaku, aturan, dan norma yang terkait dengan masalah pasar. Dengan fungsi tersebut, pasar menjadi mudah diserang dari pelanggaran-pelanggaran, praktik curang, dan ketidaakadilan yang merugikan pihak lainnya. Karena peran penting pasar tidak terlepas dengan sejumlah aturan syariat, yang antara lain terkait dengan pembentukan harga daan terjadinya transaksi di pasar. Maka pasar dalam islam dibentuk atas prinsip-prinsip sebagai berikut:

a. Ar-Ridha

Kata Ridho berasal dari bahasa Arab yaitu dari kata rodiya yang berarti senang, rela, atau suka. Ridho merupakan sifat yang terpuji yang harus dimiliki oleh manusia. Dan disini yang dimaksud ridha adalah segala bentuk transaksi yang dilakukan haruslah atas dasar senang atau rela antara masing-masing pihak. Dan juga berdasarkan Al-Quran surat An-Nisa ayat 29:

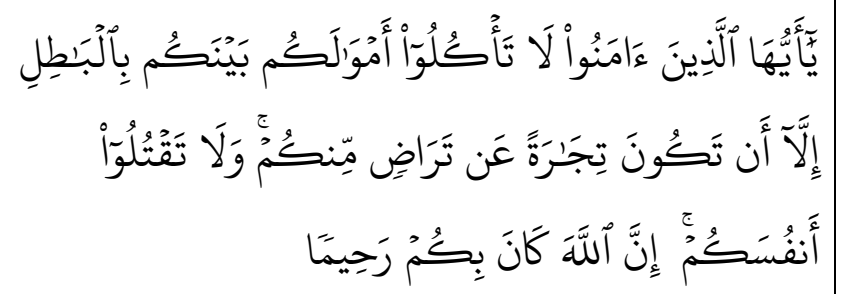

Artinya: "Hai orang-oraang yang beriman, jamganlah kamu saling memakan harta sesamamu dengan cara batil, kecuali dengan jalan perniagaan yang berlaku dengan suka sama suka diantara kamu. Dan janganlah kamu membunuh dirimu. Sesungguhnya allah adalah maha penyayang kepadamu”.

Maksud Ayat ini Allah SWT melarang mengambil harta orang lain dengan jalan yang batil (tidak benar), kecuali dengan perniagaan yang berlaku atas dasar kerelaan bersama. Sekalipun seseorang mempunyai harta yang banyak dan banyak pula orang yang memerlukannya dari golongan-golongan yang 


\section{Jurnal Ilmiah Ekonomi Islam, 6(03), 2020, 591}

berhak menerima zakatnya, tetapi harta orang itu tidak boleh diambil begitu saja tanpa seizin pemiliknya atau tanpa menurut prosedur yang sah.

b. Persaingan sehat (fair competition)

Menurut (KBBI) Kamus Besar Bahasa Indonesia persaingan adalah suatu persaingan yang dilakukan oleh seseorang atau sekolompok orang tertentu, agar memperoleh kemenangan atau hasil secara kompetitif. Persaingan yang sehat yaitu persaingan yang tidak menjatuhkan orang lain ataupun sengaja berbuat curang kepada orang lain. Di pasar pun wajib adanya persaingan sehat dengan tujuan supaya mekanisme yang telah ditetapkan di pasar tetap terjaga dan tidak akan terhambat sebab adanya ihtikar atau monopoli (Kasmir, 2012).

c. Kejujuran (honesty)

Menurut (Mustari, 2011) jujur adalah perilaku lurus hati, yang menyatakan sebenar-benarnya tidak ada kebohongan atau berkata hal-hal yang menyalahi apa yang terjadi (fakta). Islam secara tegas melarang melakukan kecurangan dan penipuan dalam bentuk apapun. Karena, nilai kebenaran ini akan berdampak langsung kepada para pihak-pihak yang melakukan aktivitas muamalah dalam perdagangan dan masyarakat umum.

d. Keterbukaan (transparency) serta keadilan (justice)

Keterbukaan atau transparansi menurut kamus besar bahasa indonesia berasal dari kata dasar terbuka dan transparan. Yaitu perwujudan sikap jujur, rendah hati, adil, serta mau menerima pendapat dan kritik dari orang lain. Sedangkan menurut (Alma, 2014) keadilan merupakan suatu keadaan dimana kebenaran ideal secara moril mengenai sesuatu hal, baik menyangkut orang atau benda. Dua prinsip ini harus diterapkan dalam kegiatan jual beli agar tidak merugikan orang lain.

\section{METODE PENELITIAN}

Jenis penelitian ini menggunakan penelitian kualitatif dengan menggunakan pedekatan yang bersifat deskriptif. Lokasi pelaksanaan penelitian bertempatan di Pasar Bandar Kecamatan Mojoroto Kota Kediri yang berlokasi di Jl. K.H. Wachid Hasyim, Bandar Lor Kota Kediri. Sumber data diperoleh dari data primer yang didapatkan dari hasil wawancara dengan penjual/pedagang dan pembeli yang ada di pasar bandar. Teknik pengumpulan data untuk penelitian ini menggunakan 3 teknik, yakni observasi, wawancara, dan dokumentasi. Sedangkan untuk teknik uji validitas data menggunakan triangulasi sumber dan untuk teknik analisis data untuk menyusun laporan ini menggunakan 3 metode yakni reduksi data, penyajian data dan yang terakhir penarikan kesimpulan.

\section{HASIL DAN PEMBAHASAN}

\subsection{Hasil penelitian}

Lokasi penelitian yang digunakan oleh peneliti adalah di Pasar Bandar Kecamatan Mojoroto Kota Kediri yang terletak di Jl. KH. Wachid Hasyim, Bandar Lor, Kec. Mojoroto, Kota Kediri, Jawa Timur. Di Pasar Bandar ini, pedagang dan pembeli dapat saling tawar menawar untuk mendapatkan kesesuaian harga yang saling menguntungkan untuk kedua belah pihak. Pedagang biasanya juga memberikan promo, diskon atau potongan harga kepada para pelanggannya. Pasar ini juga telah dimodernkan oleh pemerintah setempat supaya nyaman untuk kegiatan jual beli atau berbelanja. Pasar tradisional ini menjual berbagai macam kebutuhan pokok sehari-hari dan sembako seperti beras, gula, garam, terigu, sayur mayur, bawang, ayam, cabe, ikan dan lainnya. Kelebihan pasar tradisional ini adalah segala macam produk yang ada di jual dengan harga merakyat, sehingga bagi masyarakat itu murah, sebagaimana fungsi pasar pada umumnya.

Hasil wawancara maupun observasi yang dilakukan peneliti pada tanggal 4-6 Juni 2020 menunjukkan bahwa pedagang di pasar bandar kota kediri sudah mengetahui tentang cara/aturan berdagang dalam islam atau sesuai syariah. Dan juga sudah menerapkan prinsip-prinsip syariah yang sesuai ajaran rasul selain berpahala tapi juga dapat keuntungan yang barokah, seperti yang disampaikan oleh narasumber salah satunya yaitu $\mathrm{Bu}$ Ani (pedagang prancangan) "iyo mas, yo enek untunge gede, yo enek hikmahe barokah" ("ya, membawa keuntungan yang besar dan ada hikmahnya yaitu barokah"). Pedagang juga mengetahui bahwa segala bentuk pekerjaan apabila diniatkan ibadah akan mendapat pahala, sebagaimana yang telah disampaikan oleh salah satu narasumber yaitu Bu Nur (pedagang sayur) "nggeh mas, kulo ngerti dadi wong islam kuwi kabeh enek barokahe lak niate emang bener" ("iya, saya tau karna sebagai muslim pastinya semиa ada kebarokahan kalau ada niat yang benar").

Para pedagang juga menjelaskan bagaimana cara mereka saat melayani pelanggan, dan salah satu 


\section{Jurnal Ilmiah Ekonomi Islam, 6(03), 2020, 592}

narasumber yaitu $\mathrm{Bu}$ Ani (pedagang prancangan) menjelaskan "yo mestine sopan mas, sering senyum, pelanggan wes dianggep dulur dewe, soale akeh pelanngan yo bakale akeh dulur barang" ("ya pastinya sopan mas, dan juga banyak senyum terus juga pelanggan dianggap sebagai saudara sendiri, karena banyak pelanggan pastinya juga banyak saudara”). Dan semua pedagang menjelaskan sudah menerapkan takaran timbangan yang sesuai tanpa adanya kecurangan sedikitpun dikarenakan setiap tahunnya ada pengecekan timbangan yang dilakukan oleh pihak pengelola pasar, jadi pembeli tidak berani melakukan kecurangan. Pedagang di pasar bandar juga terkadang ada yang pernah menyampaikan hal yang tidak benar/berbohong kepada para pembeli tetapi tidak sampai merugikan pelanggan, seperti yang disampaikan narasumber Mas Ghofur (pedagang buah) "yo jujur biasane tau mas, tapi ora sampek ngerugine pelanggan dan yo gak terus-terusan" ( "ya kadang pernah mas jujur, tapi gak sampai merugikan pelanggan dan gak terus-terusan juga").

Para pedagang juga tidak pernah melanggar janji dalam berdagang, Dan para pedagang menjelaskan dengan baik apabila ada pembeli yang menawar barang dagangannya dengan harga yang rendah meskipun awalnya ada yang kesal tetapi akhirnya juga ramah, berikut yang disampaikan oleh narasumber Mas Ghofur (pedagang buah) "ya jujur ae awale gaenak mas, tapi suwi-suwi dirayu/ditawar yo tetep gelem hehee, seng penting enek komunikasi karo podo ridhone" ("ya jujur pertamanya kesal mas, tapi lama kelamaan dirayu ya mau mas, yang penting ada komunikasi dan sama-sama ridha"). Dan juga para pedagang juga menjelaskan dengan rinci dan baik apabila ada pembeli yang komplain tentang barang dagangannya, seperti yang disampaikan narasumber yaitu $\mathrm{Bu}$ Ani (pedagang prancangan) "ya wes ditrimo ae mas kan jenenge daagang, seng penting pelanggan gak mlayu dan panggah nyaman" ("ya diterima saja mas namanya juga dagang, yang terpenting pelanggan tidak lari daan tetap nyaman"). Pedagang juga menerima jika ada pembeli yang ingin mengembalikan barang asalkan dengan alasan yang jelas dan sebelumnya ada kesepakatan terlebih dahulu.

Prinsip dasar pasar islami merupakan syariah ajaran rasul yang harus diterapkan oleh para pedagang atau pelaku bisnis saat bertransaksi jual beli tujuannya untuk mencapai kebarokahan. Dan dari wawancara dan observasi didapatkan hasil:

\section{a. Ar-Ridhla}

Seperti yang sudah dijelaskan sebelumnya bawasanya Ar-Ridhla mempunyai arti senang, suka, rela. Ridhla merupakan sifat yang terpuji yang harus dimiliki oleh setiap umat muslim. Dan berdasarkan pengertian tersebut para pedagang sudah memberikan pelayanan yang baik dan ramah kepada para pembeli sehingga antara penjual dan pembeli sama-sama merasa ridhla atau senang seperti yang disampaikan $\mathrm{Bu}$ Ani (pedagang prancangan) "sering, mben tiap enek pelanggan seng ape tuku mesti melayani dengan ramah, sopan. Tujuane yo ben pelanggan kuwi tetep nyaman yo ra mlayu" ("sering, bahkan setiap ada pelanggan yang beli selalu memberikan pelayanan yang ramah. Tujuannya supaya para pelanggan tetap merasa nyaman dan tidak lari"). Dan juga dibenarkan oleh pembeli yaitusalah satunya Bu Tiwi "ya lak secara umum menurutku uwes mas" ("ya kalau secara umum menurut saya sudah").

Dan juga pedagang juga tidak keberatan memberi kesempatan kepada pembeli untuk tawar menawar harga supaya saling ridha dan tidak ada pihak yang dirugikan. Pendapat pedagang juga diperkuat oleh salah satu pembeli yaitu Pak Fauzan "aku sering mas nek pasar iki yo jenenge pedagang mesti enek seng nawar yo kuwi wajar, dadi ya gak keberatan lak seumpama ditawar" ("saya sering kepasar dan setiap pedagang mesti ada yang menawar dan itu wajar, jadi tidak keberatan kalau ditawar").

\section{b. Persaingan Sehat}

Persaingan sehat merupakan suatu kompetisi yang dilakukan oleh antar individu yang mana tidak ada cara kotor untuk menjatuhkan lawannya. Di pasar pun persaaingan sehat antar pedagang harusnya juga diterapkan agar tidak saling merugikan, dengan tidak menjelekkan barang dagangan penjual lain kepada pembeli itu sudah menjadi contoh persaingan sehat. Dan para pedagang juga tidak sungkan untuk menjelaskan bagaimana persaingan sehat antar pedagang itu, seperti yang disampaikan oleh $\mathrm{Bu}$ Ani (pedagang prancangan) "yo wajar-wajar ae mas enek persaingan nek pasar, kan seng dijual barange podo, tapi panggah gawe persaingan seng sehat yo gak ngelek-ngelekne dagangan pedagang liyane" ("ya wajarlah mas ada persaingan di pasar, yang dijual kan juga barangnya sama. Akan tetapi tetap dengan persaingan sehat dan tidak menjatuhkan pedagang yang lain"). para pedagang juga sudah menerapkan persaingan sehat antar pedagang dan para pembeli juga membenarkan hal itu seperti yang disampaikan 


\section{Jurnal Ilmiah Ekonomi Islam, 6(03), 2020, 593}

Pak Yusuf "secara umum paling uwes mas, soale nek kene kan kebanyakan pedagang wes dodolan suwi mas" ("secaara umum mungkin sudah ya, karena disini kan kebanyakn pedagang juga sudah berjualan lama"). Akan tetapi masih ada pedagang yang menjelek-jelekkan barang dagangan pedagang lain didepan pembeli, seperti yang disampaikan oleh narasumber yaitu Pak Beni (pedagang ikan) "lak mbiyen sih tau mas pas sek pertama dagang, yo kan jenenge wong dagang pengen golek untung seakehakehe, tapi suwi-suwi ya podo-podo ngertilah mas" ( "dulu sih pernah mas waktu pertama berdagang, kan namanya orang berdagang pengen cari untung banyak. Tetapi seiring berjalannya waktu sudah sama-sama mengertilah"). Dan pembeli pun juga pernah menjumpai perilaku pedagang yang seperti itu, berikut yang disampaikan oleh Pak Fauzan "mestine enek seng ngonowi mas, jenenge pedagang mesti golek untung" ("pasti ada yang seperti itu, namanya pedagang juga cari untung”).

c. Kejujuran

Jujur adalah menyatakan yang sebenar-benarnya tidak berbohong atau berkata hal-hal yang menyalahi apa yang terjadi (fakta). Islam sangat tegas tentang sifat jujur ini, karena pengaruhnya yang sangat besar. Apabila pedagang sering jujur maka sudah pasti reputasinya akan baik di pasar, pun sebaliknya jika pedagang sering berbohong maka akan jelek reputasinya dan tidak akan mendapat kebarokahan dalam berdagang. Pedagang menyampaikan tidak pernah curang dalam menimbang atau menakar, karena setiap tahunnya ada pengecekan dari pihak pengelola pasar, berikut yang disampaikan oleh Pak Beni (pedagang ikan) "insyaallah gatau mas, soale tiap tahune enek pengecekan timbangan tekan pihak pasar mas" ("insyaallah tidak pernah mas, karena setiap tahunya ada pengecekan timbangan dari pihak pasar"). Dan sudah banyak juga para pembeli mengetahui hal itu, seperti yang disampaikan oleh Pak Fauzan "aku tau diomongi sih mas karo pedagang kene lak tiap tahune emang bener enek pengecekan timbangan, yo dadine wedi gak enek seng wani curang" ("saya pernah dikasih tau sama pedagang kalau tiap tahunnya ada pengecekan timbangan, jadi tidak ada yang berani curang”. Pedagang juga terkedang pernah melebih-lebihkan kualitas produk melebihi kualitas sebenarnya dengan tujuan dan maksud yang jelas seperti yag dijelaskan narasumber yaitu $\mathrm{Bu}$ Ani (pedagang prancangan) "kadang iyo kadang ora, soale kan pedagang berusaha ngedol barang seakeh-akehe mas gawe golek untung, tapi lak emang barange sek apik ya saya ngomong jujur apik mas, kan iki ya promosi mas hehee" ("kadang iya kadang tidak, soalnya kita kan juga berusaha menjual barang sebanyak-banyaknya juga untuk mendapat untung, tetapi kalau memang barangnya bagus ya saya katakan bagus, kan kita juga promosi mas"). Dan para pembeli juga sering menjumpai dan menganggapnya dengan hal wajar seperti itu terjadi di pasar. Pedagang juga menyampaikan tidak pernah mencampur barang kualitas buruk dengan kualitas yang baik, akan tetapi para pembeli terkadang masih menjumpai pedagang yang mencampur barang dagangan kualitas jelek dengan kualitas yang bagus, seperti yang disampaikan oleh Pak Yusuf "sedurunge tuku biasane ya milih dewe ndi seng kualitase sek apik ndi seng elek, biasane ya mgomong kepedagang lak enek barang seng kualitase elek dicampur karo seng apik" ("sebelum membeli biasanya saya memilih sendiri mana yang bagus dan jelek kualitasnya, dan biasanya juga saya bilang kepedagang kalau ada barang yang kualitasnya jelek dicampur dengan yang bagus").

d. Keterbukaan

Keterbukaan sangatlah penting bagi penjual, karena dengan penjual bisa terbuka kepada pembeli atau pelanggan, maka pembeli akan merasa nyaman dan tidak akan ragu ragu untuk berbelanja. Para pedagang menjelaskan kepada pembeli atau pelanggan apabila ada kekurangan atau cacat barang sehingga tidak ada yang merasa dirugikan, seperti yang disampaikan oleh $\mathrm{Bu} \mathrm{Ani}$ (pedagang prancangan) "yo dijelasne mas opo eneke, lak enek barang seng mau expired yo diomongne nek pelanggan mending gaussah dituku, atau biasane diretur yo gapopo" ("ya dijelaskan apa adanya mas, kalau ada barang yang sebentar lagi mau expired ya dikasih tau ke pelanggan mending tidak usah dibeli, atau mungkin minta dikembalikan juga bisa"). Dan tidak lupa juga para pedagang memberikan informasi yang dibutuhkan oleh pembeli dengan jelas tentang barang dagangannya dan pembeli pun juga membenarkan seperti yang disampaikan oleh $\mathrm{Bu}$ Suntiah "ya tau, sedurunge tuku pedagang mesti njelasne disek terkadang aku seng takon mas" ("ya pernah, setiap mau beli pedagang selalu menjelaskan terkadang juga saya bertanya”). Dan pada umumnya para pedagang juga tidak pernah menimbun barang dagangannya, adapun yang menimbun itu tidak sering dan hanya sedikit tidak pernah skala besar sehingga 
merugikan pihak lain, seperti yang disampaikan oleh $\mathrm{Bu}$ Ani (pedagang prancangan) "ya koyoke tau, tapi masih skala wajar mas sek normalah, gak sampek skala gede, soale aku dewe yo wedi mas" ("ya mungkin pernah, akan tetapi masih skala wajar mas masih normalah, tidak sampai skala besar, soalnya saya juga takut mas"). Akan tetapi para pembeli tidak banyak mengetahui tentang pedagang yang menimbun barang dagangan karena tidak pernah menanyakan hal tersebut dan hanya fokus belanja saja, dan tentang pedagang yang memonopoli barang dagangan pun para pembeli tidak mengetahui banyak informasi dikarenakan alasan yang sama.

\section{e. Keadilan}

Mempunyai jiwa adil merupakan nilai tambah bagi seorang penjual. Apabila seorang penjual dapat bersikap adil kepada pembeli contohnya saja tidak membeda-bedakan harga kepada pembeli sudah dapat dipastikan jualannya insyaallah akan berkah, ditambah niat berjualan karena allah. Para pedagang juga tidak sungkan menyampaikan bagaimana cara menetapkan harga, seperti yang disampaikan oleh $\mathrm{Bu}$ Nur (pedagang sayur) "ya sedurunge kuwi dipilihi sek diurutne kualitase, ukuran, karo harag pasarane, yo intine meh podo mas karo pedagang liane, golek untungpun yo wajar gak akeh-akeh" ("ya sebelumnya dipilih dulu berdasarkan kualitas, ukuran, dan harga pasaran, ya intinya hampir sama lah mas dengan pedagang lain, mencari untung pun tidak banyak dan sewajarnya"). Dan pembeli juga menyampaikan pendapatnya tentang cara pedagang menetapkan harga, seperti yang disampaikan Bu Suarti "ya pedagang paling wes ngerti lak bahasane iku wes memperhitungkan kualitas karo harga seng pas, memperhitungkan modal dan untungnya" ("ya pedagang mungkin sudah tahu lah atau bahasanya itu sudah memeprhitungkan kualitas dengan harga yang pas, memperhitungkan modal dan untungnya"). Dan pedagang bersedia apabila ada pembeli yang ingin mengganti atau menukar kembali barang dagangan yang ada cacatnya asalkan sebelumnya ada kesepakatan berasama dan ada alasan yang jelas. Hal ini pun juga dibenarkan oleh para pembeli, seperti yang disampaikan oleh $\mathrm{Bu}$ Tiwi "menurutku yo sedurunge mesti enek kesepakatan antara pembeli karo penjual, sedurunge tukar barang, terus menurutku pedagang yo gak keberatan mas" ("menurut saya ya sebelumnya ada kesepekatan antara pedagang dan pembeli, sebelum mau menukarkan barang, dan menurut saya pedagang juga tidak keberatan”). Pedagang juga memberikan harga yang sama kepada pembeli yang berbeda dengan satu harga, dan ada juga yang memberi harga yang berbeda kepada pelanggan setia ataupun saudara seperti yang disampaikan oleh $\mathrm{Bu}$ Ani (pedagang Prancangan) "yo gak mestu mas, kadang lak seng tuku dulure dewe ya regane bedo hehe kadang dikasih rego murah terus nek pelanggan setia kadang dikasih diskon atau bonus" ("ya tidak mesti, kadang kalau saudara yang beli ya beda harganya atau dikasih murahlah atau dengan pelanggan yang sering beli kadang minta dikasih diskon atau bonus").

\subsection{Pembahasan}

Berdasarkan analisis dari wawancara dan observasi yang telah dilakukan kepada pedagang di pasar bandar kecamatan kota kediri, dari segi perilaku pedagang dipaparkan bahwa telah banyak pedagang yang telah mengetahui etika berdagang yang sesuai syariah meskipun pada dasarnya pasar bandar adalah pasar tradisonal biasa atau konvensional dan bukan pasar syariah. Menurut penuturan salah satu narasumber dikatakan semua pedagang pada dasarnya sedikit banyak mengetahui tentang cara atau aturan berdagang yang sesuai syariah. pedagang di pasar bandar sudah banyak yang menerapkan tata cara berdagang sesuai syariah, karena para pedagang juga mengetahui bahwa dengan menerapkan perdagangan secara syariah akan membawa keuntungan yang berkah. Dan juga tidak lupa dipaparkan para pedagang sangat mengerti apabila segala macam bentuk pekerjaan apabila diniatkan ibadah maka akan berpahala ibadah pula ataupun kebarokahan dalam berdagang

Kemudian narasumber juga memaparkan cara saat melayani pelanggan atau pembeli. Salah satu narasumber menjelaskan saat melayani pelanggan maka pedagang bersikap ramah, berkata sopan, dan menjelaskan apa yang dibutuhkan oleh pembeli secara jelas sehingga pembeli merasa nyaman, serta mendapatkan apa yang diinginkan dan akhirnya menjadi pelanggan tetap. . Berdasarkan hasil pengamatan penulis juga melihat bawasanya para pedagang memang benar sudah menerapkan tata cara berdagang yang baik salah satunya dengan bersikap ramah kepada setiap pembeli atau pelanggan. Sedangkan mengenaai takaran timbangan narasumber juga memaparkan bahwasanya selama menjadi pedagang di pasar bandar tidak pernah berlaku curang dalalm menakar atau menimbang barang dagangan. 


\section{Jurnal Ilmiah Ekonomi Islam, 6(03), 2020, 595}

Menurut salah satu narasumber setiap tahunnya pihak pengelola pasar akan mengecek timbangan para pedagang sehingga insyaallah tidak ada pedagang yang berlaku curang dalam menakar atau menimbang. Dan penulis juga menyaksikan langsung dari hasil pengamatan bawasanya setiap pedagang benar-benar sesuai dan jujur mengenai takaran timbangan tidak dikurangi atau dilebihkan, bahkan terkadang diberi bonus untuk pelanggan setia.

Narasumber juga memaparkan tidak pernah berkata bohong kepada pelanggan tentang barang dagangannya dan ada yang berbohong tetapi jarang dan masih bisa dikatakan wajar dan tidak sampai merugikan pembeli, karena menurut salah satu pedagang wajar apabila di pasar ada pedagang yang seperti itu akan tetapi sebisa mungkin tidak kelewat batas dan tidak sampai merugikan pelanggan. Penulis juga menyaksikan berdasarkan hasil pengamtan salah satu pedagang buah berbohong kepada pembeli tentang kualitas buahnya yang katanya buahnya baru datang padahal sebelumnya menjelaskan kepada penulis bawasanya buahnya baru distok kemarin, akan tetapi kualitasnya masih segar dan baik. Dan juga narasumber memaparkan tidak pernah melanggar janji dalam berdagang karena itu akan merugikan para pedagang itu sendiri karena berperilaku apa adanya selama berdagang justru mebuat kenyaman bagi pedagang maupun pembeli itu sendiri. Dan juga tidak lupa salah satu narasumber memaparkan sikap ketika ada pembeli yang menawar barang dagangan dengan harga yang lebih rendah yaitu terkadang ada pedagang yang awalnya kesal, akan tetapi setelah dibujuk akhirnya juga mau menerima. Yang terpenting ada komunikasi dan pelanggan merasa nyaman dan tidak lari. Karena siapa tau pembeli itu nantinya akan jadi pelanggan tetap dan sering datang untuk belanja kepadanya.

Narasumber lainnya juga memaparkan apabila ada pelanggan yang komplain tentang barang dagangannya maka pedagang akan menerima dan bertanya apa yang membuat pelanggan itu komplain dan tetap melayani dengan ramah dan sopan agar pelanggan juga merasa nyaman dan tidak merasa sakit hati. Dan salah satu narasumber memaparkan jika ada pembeli yang ingin mengembalikan barang dagangannya maka pedagang akan menerima tetapi dengan syarat dan alasan yang masuk akal dari pembeli yang ingin mengembalikan barang dagangannya yang telah dibeli tersebut tujuannya agar sama-sama tidak merasa dirugikan. Dan penulis juga melihat langsung dari hasil pengamatan ada negosiasi antara penjual sayur dan pembeli tentang barang dagangan, dan melihat bagaimana penjual sayur tetap melayani dengan baik bahkan kadang juga becanda kepada pembeli.

Berdasarkan analisis dari wawancara dan observasi yang telah dilakukan kepada pedagang dan pembeli di pasar bandar kecamatan mojoroto kota kediri menurut kesesuian prinsip syariah atau prinsip dasar islami yaitu:

a) Menurut prinsip Ar-Ridhla telah dipaparkan narasumber bahwasanya pedagang di pasar bandar secara umum sudah memberikan pelayanan yang baik atau ramah kepada pembeli dan kebanyakan pembeli juga merasa dilayani dengan baik. Dan pedagang juga tidak keberatan memberi kesempatan kepada pembeli atau pelanggan untuk bernegoisasi mengenai harga yang cocok antara kedua belah pihak. Pengamatan yang dilakukan oleh penulis juga menyaksikan bagaimana saat penjual dan pembeli bertransaksi, penjual dengan ramahnya melayani pembeli dengan baik dan pembeli juga berkata halus dan baik saat bertransaksi.

b) Menurut prinsip persaingan sehat juga telah dipaparkan narasumber bahwa pedagang di pasar bandar secara umum sudah mengetahui apa itu persaingan sehat dan juga sudah banyak yang menerapkannya. Dan para pembeli pun juga banyak yang membenarkan itu. Meskipun terkadang masih dijumpai pedagang yang menjelek-jelekkan dagangan pedagang lain didepan pembeli untuk mencari keuntungan. Penulis juga mengamati dan melihat salah satu penjual prancangan ketika pembeli mencari barang yang dicari dan ternyata dikiosnya tidak ada atau sudah habis barang tersebut, maka penjual tersebut langsung inisiatif mengarahkan pembeli ke kios disebelahnya dan akhirnya barang dicari itu ada.

c) Menurut prinsip kejujuran telah dipaparkan narasumber pula bahwa pedagang di pasar bandar sudah menerapkan kejujuran dengan tidak pernah curang dalam menakar dan menimbang karena setiap tahunnya ada pengecekan dari pihak pengelola pasar dan sudah banyak pembeli yang tau tentang pengecakan timbangan tersebut. Penulis juga mengamati langsung salah satu pedagang ikan saat menimbang meminta pembeli melihat langsung bahwa takarannya sudah benar 


\section{Jurnal Ilmiah Ekonomi Islam, 6(03), 2020, 596}

dan pas. Pedagang juga tidak pernah mencampur dagangannya yang kualitas baik dengan kualitas yang kurang baik karena sebelumnya sudah disortir atau dipilih-piluh dulu menurut kualitasnya, meskipun terkadang masih ada pembeli yang menjumpai ada yang mencapur barang dagangannya. Akan tetapi masih dijumpai juga pedagang yang terkadang melebih-lebihkan kualitas produk melebihi kualitas aslinya dan pembeli juga banyak yang membenarkan, meskipun bagi pedagang masih sebatas wajar dan tidak sampai merugikan pelanggan. Dan penulis juga mengamati ada pedagang sayur yang melebih-lebihkan kualitas dagangannya tetapi juga menjelaskan kepada pembeli dengan baik.

d) Menurut prinsip keterbukaan telah dipaparkan narasumber bahwa pedagang di pasar bandar sudah menerapkan dengan baik mulai dari menjelaskan kepada pembeli atau pelanggan kekurangan dan kecacatan barang dagangannya yang dijual dengan baik dan jelas. Dan pedagang juga memberikan informasi yang dibutuhkan oleh pembeli sehinggan pembeli merasa terbantu dan nyaman untuk berbelanja. Serta menulis juga menyaksikan langsung dari hasil pengamatan bahwa penjual memang sudah baik dalam menjelaskan kepada calon pembeli. Dan untuk menimbun barang dagangan secara umum sudah tidak ada yang menimbun barang kalaupun ada itu tidak sampai menimbun skala besar dan merugikan banyak pihak. Meskipun dari sudut pandang pembeli tidak banyak yang mengetahui informasi tersebut dikarenakan para pembeli hanya fokus belanja dan tidak pernah menanyakan tentang penimbunan barang dagangan ataupun memonopoli barang dagangan.

e) Menurut prinsip keadilan telah dipaparkan narasumber bahwa pedagang di pasar bandar secara umum bersedia menerima dan mengganti barang dagangan apabila ada pelanggan yang merasa barang yang dibelinya itu ada kecacatan dengan syarat ada kesepakatan terlebih dahulu dan alasan yang jelas agar tidak merugikan satu sama lain. Dan pedagang juga sudah menerapkan harga yang sama kepada pembeli yang berbeda meskipun ada harga khusus bagi saudara atau pelanggan tetap dan itu masih wajar. Penulis juga melihat langsung bagaimana ramahnya penjual saat melayani pembeli bahkan kepada pelanggan setia mulai dari saling becanda sampai ada yang diberi bonus.

\section{KESIMPULAN}

Berdasarkan dari hasil penelitian wawancara dan observasi yang telah disebutkan mengenai perilaku pedagang di pasar Bandar Kecamatan Mojoroto Kota Kediri, maka dapat ditarik kesimpulan bahwa perilaku pedagang di pasar bandar sudah baik dan tepat meskipun pada dasarnya pasar Bandar merupakan pasar tradisional biasa atau konvensional dan bukan pasar yang menerapkan prinsip syariah didalamnya. Dan untuk segi kesesuaian prinsip dasar pasar islami yaitu diantaranya prinsip ar-ridhla, prinsip persaingan sehat, prinsip kejujuran, prinsip keterbukaan, serta prinsip keadilan, pedagang di pasar Bandar sudah menerapkan prinsip-prinsip dasar islami tersebut dengan cukup baik, meskipun begitu masih banyak hal yang harus dibenahi seperti masih dijumpai pedagang yang berbohong kepada pembeli atau pelanggan, maka akan lebih baik apabila para pedagang sebagai seorang muslim dapat menerapkan kejujuran yang baik dan utuh agar dapat kaffah dalam memeluk dan menjalankan agama islam serta insyaallah pasti akan mendapat pahala dan kebarokahan dalam berdagang. Dan adapun untuk keterbatasan penelitian yang dialami oleh peneliti adalah objek penelitian yang hanya berfokus pada pedagang dan pembeli di pasar Bandar saja.

\section{UCAPAN TERIMA KASIH}

Puji syukur penulis panjatjan kepada Allaah SWT dengan segala rahmat serta karunia-Nya yang telah memberikan nikmat kesehatan, kekuatan dan kesabaran sehingga penulis dapat menyelesaikan artikel ilmiah ini. Penulis juga mengucapkan terima kasih yang sebesar-besarnya kepada semua pihak yang telah membantu. Penulis banyak menerima bimbingan, dorongan, bantuan, serta petunjuk dari berbagai pihak baik yang bersifat moral maupun material, kepada kedua orang tua yang terus mendukung dan mendoakan, kemudian kepada kakak Fantiko Nugroho dan adik Shela yang juga mendukung, kepada dosen pembimbing Bu Khusnul Fikriyah ,S.E.,M.SEI. yang terus membirikan bimbingan, arahan, dan semangat kepada penulis, kepada dekan Fakultas Ekonomi Universitas Negeri Surabaya Bapak Dr. Anang Kistyanto, S.Sos, dan Kajur jurusan ilmu ekonomi Ibu Dr. Sri Abidah Suryaningsih S.Ag., M.Pd, seluruh dosen dan staf 
akademik Fakultas Ekonomi khususnya Jurusan Ilmu Ekonomi Universitas Negeri Surabaya, kepada pedagang dan pembeli pasar bandar kota kediri yang telah membantu penelitian penulis, kepada teman Bagas yang telah mau meminjamkan laptopnya, dan juga teman Arimbi yang telah membantu membuatkan abstrak, kepada teman seangkatan jurusan ilmu ekonomi prodi ekonomi islam 16, serta semua dukungan teman-teman dari PPPM BM Surabaya. Semoga Allah SWT senantiasa membalas semua kebaikan yang telah diberikan. Dan ssemoga penelitian ini bisa bermanfaat untuk orang banyak.

\section{REFERENSI}

Al-Qur'an surat Asy-Syu'ara ayat 181-183

Al-Qur'an surat An-Nisa' ayat 29

Alma, B. (2014). Manajemen Bisnis Syariah : Menanamkan Nilai dan Praktik Syariah Dalam Bisnis Kontemporer. Bandung: CV. Alfabeta.

Amalia. (2014). Etika Bisnis Islam: Konsep dan Implementasi pada Pelaku Usaha Kecil. Jurnal Ilmu Ekonomi Syariah.

Arifin, J. (2013). Etika Bisnis Islami. Semarang: Walisongo Press.

Aziz, A. (2013). Etika Bisnis Prespektif Islam. Bandung: Alfabeta.

Christine, K. d. (2008). Pokok-Pokok Pengetahuan Hukum Dagang Indonesia. Jakarta: Sinar Grafika.

Dewi, W. (2011). Teori \& Pengukuran Pengetahuan, Sikap, dan Perilaku Manusia. Yogyakarta: Nuha Medika.

Faidah, R. d. (2020). Survival of Traditional Retailers: An Islamic Business Perspective. Al-Uqud: Journal of Islamic Economics.
Fauzia, I. Y. (2017). Etika Bisnis Dalam Islam. Jakarta: Kencana Prenada Media Group.

Karim, A. A. (2010). Ekonomi Mikro Islam. Jakarta: Rajawali Pers.

Kasmir. (2012). Kewirausahaan. Jakarta: PT Raja Grafindo Persada.

Lukito, Y. N. (2018). Revitalisasi Ruang Pasar Tradisional Melalui Pendekatan Desain dan Interaksi Pengguna Ruang Penulis. Yogyakarta: Deepublish.

Malano, H. (2011). Selamatkan Pasar Tradisonal. Jakarta: PT Gramedia Pustaka Umana.

Mustari, M. (2011). Nilai Karakter. Yogyakarta: LaksBang PRESSindo.

Notoatmodjo. (2010). Ilmu Perilaku Kesehatan. Jakarta: Rineka Cipta.

Puspitasari, I. (2019). Analisis Praktik Etika Bisnis Syariah (Studi Kasus Pasar Leuwiliang). Jurnal Ekonomi dan Keuangan Syariah.

Ramadhan, M. N. (2015). Etos Kerja Islami Pada Kinerja Bisnis Pedagang Muslim Pasar Gede Madiun. JESST.

Rivai, V. (2010). Islamic Bussiness and Economic Ethic: Mengacu Pada Al-Quran dan Mengikuti Jejak Rasulullah SAW Dalam Bisnis, Keuangan, dan Ekonomi. Jakarta: Bumi Aksara.

Rohmansyah. (2017). Fiqh Ibadah dan Mu'amalah. Yogyakarta: LP3M Universitas Muhammadiyah Yogyakarta.

Wulandari, D. (2019, september 20). tabloidjubi.com. Diambil kembali dari tabloidjubi.com: jubi.co.id: http:jubi.co.id 